\title{
The volume fraction method for the evaluation of kidney: A stereological study
}

\author{
Gulsun PAZVANT ${ }^{1 *}$, Bunyamin SAHIN ${ }^{2}$, K.Oya KAHVECIOGLU ${ }^{1}$, Halil GUNES ${ }^{3}$, \\ Nazan GEZER INCE ${ }^{1}$, Defne BACINOGLU ${ }^{1}$
}

\author{
${ }^{1}$ Istanbul University, Faculty of Veterinary Medicine, Department of Anatomy, Istanbul; ${ }^{2}$ Ondokuz Mayis University, Faculty of \\ Medicine, Department of Anatomy, Samsun; ${ }^{3}$ Istanbul University, Faculty of Veterinary Medicine, Department of Animal Breeding \\ and Husbandry, Istanbul, Turkey.
}

\begin{abstract}
Summary: It is known that the kidney size is related to body height, body surface area and body weight. In the present study we propose the volume fraction approach of stereological methods that eliminate the effects of body size over the quantitative evaluation of cortex, medulla and pelvis of kidney. Kidneys were removed from 20 Kivircik sheeps and their volumes were measured using the Archimedean principle. The total volume and volume of its components and the volume fraction of cortex, medulla and the pelvis were estimated stereologically. The mean kidney volumes were $61.3 \pm 12.7 \mathrm{~cm}^{3}$ and $59.7 \pm 12.8 \mathrm{~cm}^{3}$, using the Archimedean and the Cavalieri principles, respectively. The obtained values were not found to be significantly different ( $>0.05$ ). The kidney was composed of $69.7 \pm 3.0 \%$ cortex, $27.1 \pm 2.9 \%$ medulla and $3.2 \pm 0.7 \%$ pelvis. Our results show that the stereological method applied in this study provides unbiased data about the volumetric characteristics of kidney and can be used on physical section of the evaluation of the volume and volume fractions of kidney and its subcomponents.
\end{abstract}

Key words: Cavalieri principle, renal cortex, renal medulla, renal pelvis, stereology

\section{Böbrek değerlendirmesi için hacimsel oran metodu: Stereolojik çalışma}

Özet: Böbrek büyüklüğünün, vücut yüksekliği, vücut yüzey alanı ve vücut ağırlığı ile ilişkili olduğu bilinmektedir. Yapılan bu çalışmada, korteks, medulla ve böbrek pelvisinin rakamsal değerlendirilmesi üzerinde vücut büyüklüğünün etkilerini elimine etmek amacı ile, stereolojik metodlardan hacimsel oran yaklaşımı kullanılmıştır. Materyal olarak 20 adet Kıvırcık koyunundan elde edilen böbreklerin hacmi Arşimed prensibi kullanılarak ölçülmüştür. Ayrıca bu böbreklerin toplam hacmi ve korteks, medulla ve pelvis bölümlerinin hacmi stereolojik olarak tahmin edilmiş̧ir. Arşimed ve Cavalier metodları kullanılarak elde edilen ortalama böbrek hacimleri sırası ile, $61.3 \pm 12.7 \mathrm{~cm}^{3}$ ve $59.7 \pm 12.8 \mathrm{~cm}^{3}$ olarak ölçülmüştür. Elde edilen veriler istatistiki olarak önemli bulunmamıştır

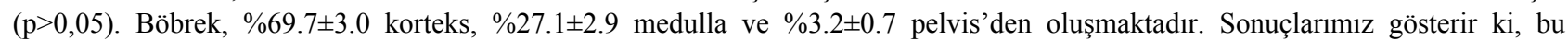
çalı̧̧mada kullanılan stereolojik metodlar, böbreğin hacimsel karakteristikleri hakkında ön yargısız bilgi sağlar ve böbrek hacmi, hacimsel oranları ve alt bölümlerinin değerlendirilmesinde kullanılabilir.

Anahtar sözcükler: Cavalier prensibi, cortex renalis, medulla renalis, pelvis renalis, stereoloji.

\section{Introduction}

Renal volume is clinically important data because renal size gives insight into renal functional reserve (8, 26). Kidney volume and the thickness of the total parenchyma or renal cortex have been used to predict overall renal function in normal individual and in those with chronic renal disease (31). Cortical thickness and cortical area have been shown to be useful for the prediction of the presence of unilateral renal artery stenosis with far greater sensitivity and accuracy than renal bipolar length in patients with early atherosclerotic renovascular disease or fibromuscular dysphasia $(7,21$, 22).

The volume of biological structures can be obtained by the Cavalieri principle of stereological volume estimation as described in the previous studies $(3,9,24$, 28). This approach allows the evaluation of the volumes of macroscopic and microscopic tissues $(25,27)$ on the basis of physical sections. With the aid of this method it is possible to estimate the volume of any object either in isolated state or immersed within an organ.

Kidney is an organ that vary widely in size. To date, scientists have documented several factors that contribute to this variation. Factors related to kidney growth, such as gender and physical size, affect the maximal size of an individual's kidney $(15,16,23,30)$. Comparing solely the kidney volumes between two groups (i.e. control and experimental groups) may not provide reliable data. For scientific purposes it seems crucial that any evaluation of kidney size should take body composition into consideration (30). At this point, the volume fraction approach of stereological methods could be an alternative way for the evaluation of kidney composition, which allows the size relation of the components of kidney (i.e. 
cortex, medulla and pelvis) independent from the body size of subject.

The aim of this study is to present a new method that could be used to estimate the percentages of the cortex, medulla and pelvis of kidney.

\section{Materials and Methods}

In this study, left and right kidneys taken from slaughter house, were removed from 20 (10 male, 10 female) Kivircik sheep of average age of 1 year after weighing their carcasses. Kidneys were soaked in $10 \%$ formalin solution for 10 days. Total volumes of kidneys were measured in a graded cylinder applying the Archimedean principle. Using a salami slicer machine, kidneys were sliced to produce $0.65 \mathrm{~cm}$ wide parallel sections (Figure 1). Depending on the size of the kidneys, 8 to 11 sections were obtained for volume estimation. The volume of whole kidney and its subcomponents (i.e. cortex, medulla and pelvis) and volume fraction of cortex, medulla and pelvis were estimated separately using the methods described below.
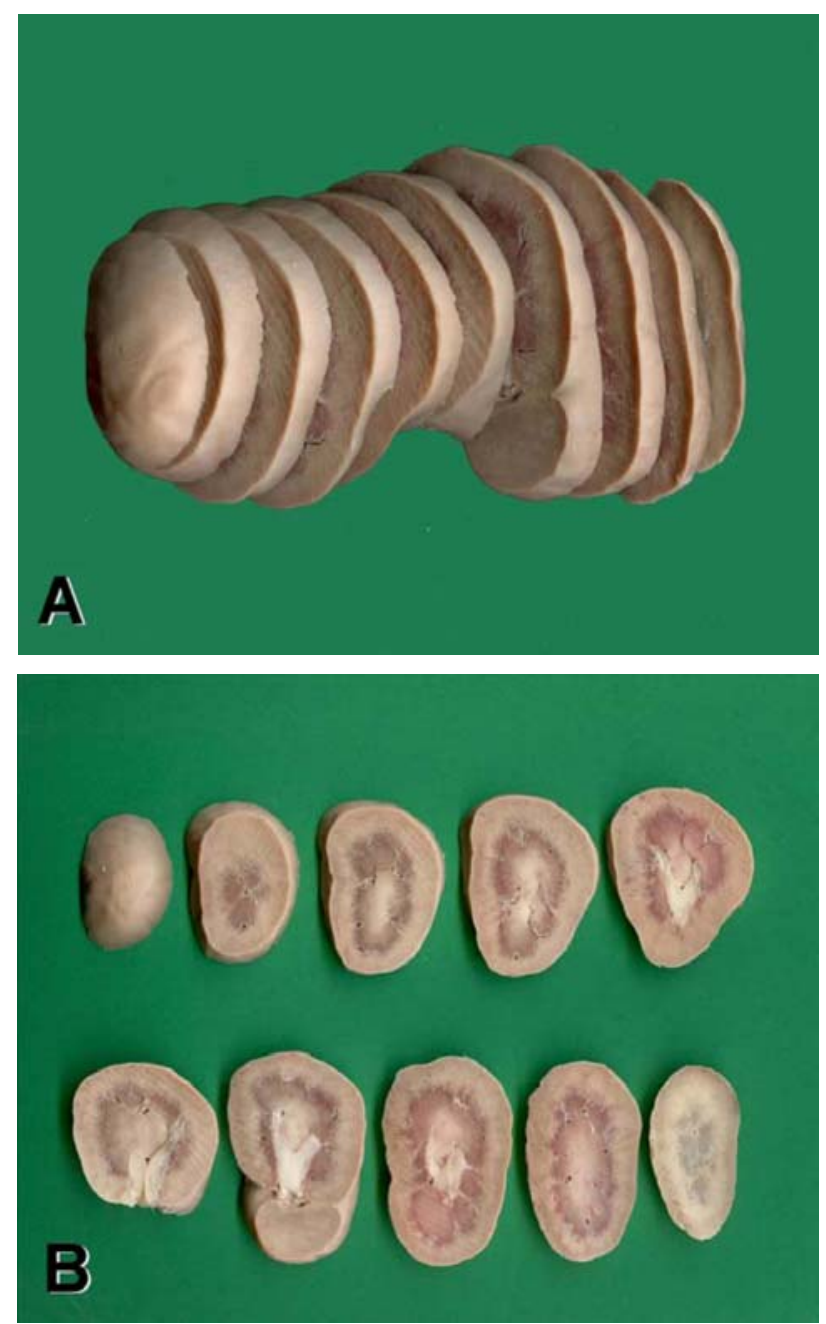

Figure 1. A: kidney slices cut in parallel sections; B: the slices ready for superimposition of the grid.

Şekil 1. A. Paralel dilimlenmiş böbrek kesitleri; B: Noktalı ölçüm alan cetveli konmak üzere hazırlanmış dilimler.
Volume estimation: In order to estimate the volumes of the whole kidney and its components, a common point counting grid with $1 / 4$ area fraction was used. This grid system was superimposed covering the slab's sectioned surface area and only the circled points $(\oplus)$ with $0.5 \mathrm{~cm}$ distance between test points were counted for the estimation of total kidney volume and cortical volume. Both the circled and non-circled points $(0.25 \mathrm{~cm}$ distance between test points) were counted for the estimation of the volume of medulla, and pelvis (Figure 2). Previously defined corner of the crosses in the grid (i.e. upper right corner) was assessed as the point. The number of points (i.e. corners) hitting the examined structure was recorded for the stereological estimates. The following formula was used to estimate the volumes of the kidneys and their subcomponents by counting the intersecting points between the grids and the regions of interest (11).

$$
V=t \times a(p) \times \Sigma P
$$

$t \quad$ : Section thickness $(0.65 \mathrm{~cm})$

$a(p)$ : The area represented by a point in the grid $(0.25$ or $0.0625 \mathrm{~cm}^{3}$ )

$\Sigma P$ : Total number of points hitting the surface area of sections
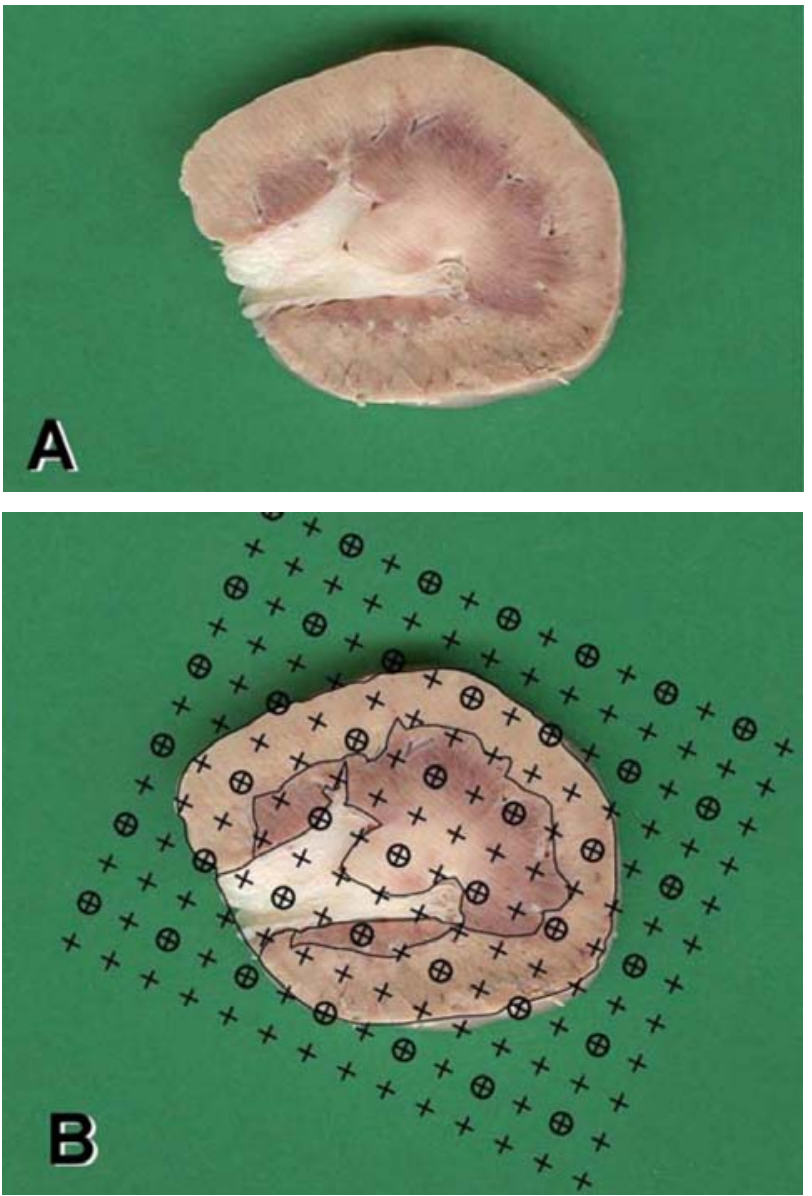

Figure 2. Estimation of the area of the slice using a transparent point grid. A: a kidney slice, B: superimposition of the grid covering the slice.

Şekil 2. Şeffaf noktalı alan ölçüm cetveli kullanılarak dilimin alanının hesaplanması. A: Böbrek dilimi, B: Dilimi kaplayan noktalı alan ölçüm cetveli. 
Volume fraction estimation: The volume fraction is used to express the proportion of a phase or component within the whole structure. The volume fraction of an $X$ phase within a $Y$ reference volume is simply expressed as follows:

$$
V_{V}(X, Y)=\frac{\text { Volume of } X \text { phase in } Y \text { reference space }}{\text { Volume of } Y \text { reference space }}
$$

Using this approach, $\mathrm{V}_{\mathrm{V}}$ (hippocampus, brain), $\mathrm{V}_{\mathrm{V}}$ (renal cortex, kidney) and $\mathrm{V}_{\mathrm{V}}$ (renal medulla, kidney) can be estimated. Volume fraction ranges from 0 to 1 and is often expressed as a percentage $(1,14)$.

The volume fraction of a phase can be estimated on sections using a point-counting approach (1, 19). The volume fraction formula with the combination of a pointcounting grid can be written as follows:

$$
V_{V}(X, Y)=\frac{\Sigma P_{X}}{\Sigma P_{Y}}
$$

where ' $\Sigma P_{X}$ ' indicates the number of points hitting the $X$ phase and ' $\Sigma P_{Y}$ ' the number of points hitting the reference space $Y$.

Usually, the phase volume within the reference space is smaller in size. In this case, the use of a simple point counting grid can provide sufficient sampling opportunity for the section cut surface area of the reference space, but not for the phase. The combined point counting grids (CPCG) could be used to give equal sampling opportunity to both of them. A combined point counting grid is composed of two sets of points of different densities on the same grid. Figure 3 illustrates a CPCG that has four fine points (crosses and encircled crosses) per coarse point (i.e. encircled crosses only). We can describe this grid as a CPCG with $1 / 4$ area fraction. The area per point associated with each coarse point is thus four times larger than that of each fine point; one should consider that encircled points are used as both fine and coarse points.

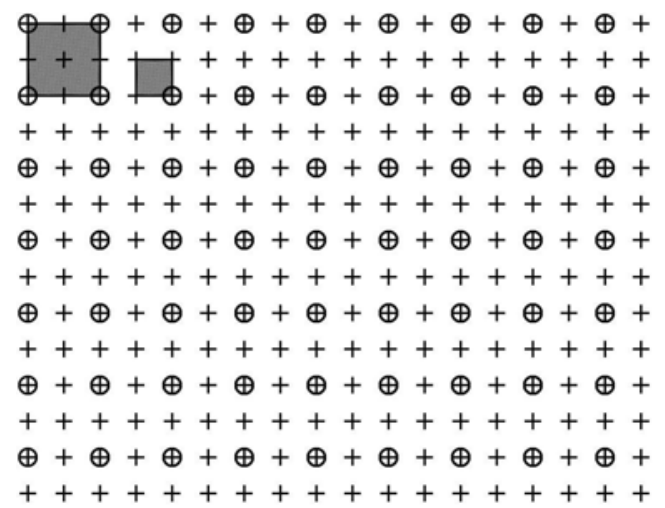

Figure 3 . A combined point counting grid with $1 / 4$ area fraction. While an encircled cross represents a large area, each cross without a circle represents $1 / 4$ fraction of the large areas.

Şekil 3. 1/4 ölçekli bir bileşik noktalı alan ölçüm cetveli. Yuvarlak içine alınmış bir artı işareti büyük alanı temsil ederken, daire içerisine alınmış ya da alınmamış bir artı işareti ise büyük alanın $1 / 4$ 'ünü temsil eder.
The volume fraction of a component within the reference space can be estimated by placing the CPCG over the section, counting the number of coarse points that hit the reference space including the phase, and counting all points hitting only the phase. As the ratio of fine to coarse points is $1 / 4$, a slightly modified version of equation \#3 can be used to estimate the volume fraction of a component within the reference space.

$$
V_{V}(X, Y)=\frac{\Sigma P_{X}}{4 \times \Sigma P_{Y}}
$$

We estimated the volume fraction of the cortex within the whole kidney by means of the following formula.

$$
V_{V}(\text { cortex }, \text { kidney })=\frac{\sum P_{\text {cortex }}}{\sum P_{\text {kidney }}}
$$

The volume fractions of the medulla and pelvis within the whole kidney were estimated by means of the following formula.

$$
V_{V}(\text { medulla or pelvis, kidney })=\frac{\Sigma P_{\text {medulla or pelvis }}}{4 \times \Sigma P_{\text {kidney }}}
$$

where, $\Sigma \mathrm{P}_{\text {cortex }}, \Sigma \mathrm{P}_{\text {medulla or pelvis }}$ is the total number of points hitting the components of kidney (i.e. cortex, medulla or pelvis) and $\Sigma \mathrm{P}_{\text {kidney }}$ is the total number of points hitting sectioned surface of kidney including all components. While only the encircled crosses hitting the whole kidney and cortex were counted, both crosses were counted in case of hitting medulla and pelvis. (Figure 2). The value obtained is the volume fraction of the component within the kidney expressed as a percentage $(14,17,18)$. The application of the described approaches for the estimation of volume and volume fraction are presented in Table 1.

Table 1. An example of the application of volume and volume fraction method described in the present study. $a(p)=0.25 \mathrm{~cm}^{2}$ for total kidney and cortex; $a(p)=0.625 \mathrm{~cm}^{2}$ for medulla and pelvis; $\mathrm{t}=0.65 \mathrm{~cm}$.

Tablo 1. Çalışmada tanımlanan hacim ve hacim oranı yönteminin uygulanışını gösteren bir örnek. Tüm böbrek ve korteks için $\mathrm{a}(\mathrm{p})=0.25 \mathrm{~cm}^{2}$; medulla ve pelvis için $\mathrm{a}(\mathrm{p})=0.625 \mathrm{~cm}^{2} ; \mathrm{t}=0.65 \mathrm{~cm}$.

\begin{tabular}{ccccc}
\hline Section no: & \multicolumn{4}{c}{ Numbers of points hitting } \\
& Kidney & Cortex & Medulla & Pelvis \\
\hline 1 & 34 & 32 & 2 & 0 \\
2 & 41 & 34 & 38 & 0 \\
3 & 61 & 37 & 97 & 0 \\
4 & 69 & 39 & 109 & 9 \\
5 & 65 & 44 & 60 & 21 \\
6 & 45 & 27 & 57 & 15 \\
7 & 39 & 22 & 57 & 12 \\
8 & 45 & 30 & 47 & 11 \\
9 & 42 & 25 & 67 & 0 \\
10 & 39 & 26 & 52 & 0 \\
11 & 28 & 24 & 17 & 0 \\
Total numbers of & 508 & 340 & 603 & 68 \\
points $(\Sigma$ P) & & & &
\end{tabular}




$$
\begin{aligned}
& V_{\text {whole kidney }}=t \times a(p) \times \Sigma P=0.65 \times 0.25 \times 508=82.55 \mathrm{~cm}^{3} \\
& V_{V}(\text { cortex, kidney })=\frac{\Sigma P_{\text {cortex }}}{\Sigma P_{\text {kidney }}}=\frac{340}{508}=0.67=67 \%
\end{aligned}
$$

The coefficient of error (CE) was calculated. Accordingly, the efficiency of sampling and the density of grid points were performed as documented in the literature $(12,27,29)$. All calculations and other related data were obtained as a spreadsheet using Microsoft Excel. After the initial setup and preparation of the formulae, the point counts and other data were entered for each subject and the final data was obtained automatically.

The statistical comparison of the volumes of kidneys taken from carcasses, which were measured using Archimedean principle and estimated using stereological techniques, was carried out with Student's ttest. The volume fraction values between the genders and right-lefts sides were compared using Student's t-test.

\section{Results}

The mean carcass weight $( \pm \mathrm{SD})$ measured in this study was $25.5 \pm 4.2 \mathrm{~kg}$. The carcass weights of the male sheep were heavier than the carcass weights of the female sheep (male: $27.3 \pm 4.3 \mathrm{~kg}$, female: $23.7 \pm 3.4 \mathrm{~kg}$ ). The difference in carcass weight between the genders was statistically significant $(\mathrm{p}<0.05)$.

Volumetric data: The mean kidney volume $( \pm \mathrm{SD})$ measured using the Archimedean principle was $61.3 \pm 12.7 \mathrm{~cm}^{3}$. The kidney volume of the male sheep investigated in this study was larger than the kidney volume of the female sheep (male: $69.6 \pm 10.8 \mathrm{~cm}^{3}$, female: $53.0 \pm 8.3 \mathrm{~cm}^{3}$ ). The difference in kidney volume between the genders was statistically significant $(\mathrm{p}<0.05)$.

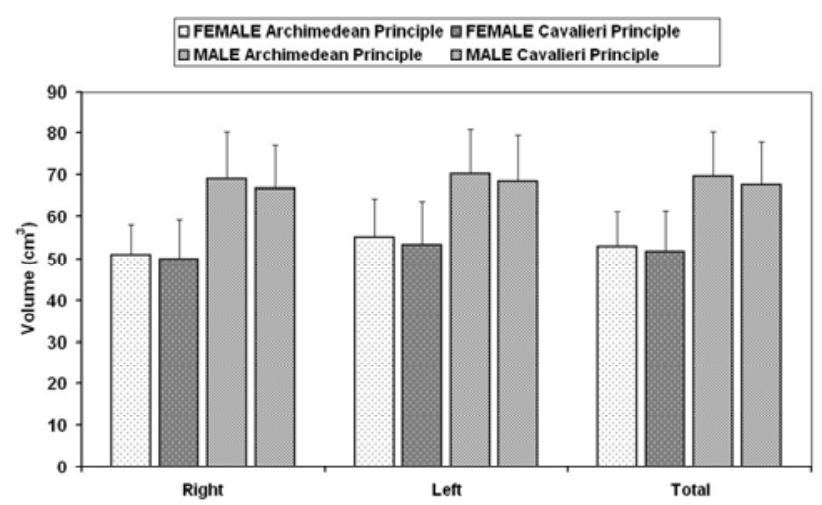

Figure 4. Total volume of kidneys $\left(\mathrm{cm}^{3} \pm \mathrm{SD}\right)$ obtained using Archimedean and the Cavalieri principles.

Şekil 4. Arşimed ve Cavalier metodları kullanılarak elde edilen total böbrek hacimleri $\left(\mathrm{cm}^{3} \pm \mathrm{SD}\right)$
The mean kidney volume estimated stereologically was $59.7 \pm 12.8 \mathrm{~cm}^{3}$. The kidney volume of the male sheep was larger than the kidney volume of the female sheep (male: $67.6 \pm 10.5 \mathrm{~cm}^{3}$, female: $51.7 \pm 9.7 \mathrm{~cm}^{3}$ ). The difference in kidney volume between the genders was statistically significant $(\mathrm{p}<0.05)$. No statistically significant difference was observed between the values obtained using the Archimedean and the Cavalieri principles ( $p>0.05)$ (Figure 4). Neither the results of Archimedean principle nor the Cavalieri principle did show statistically significant differences between the right and left sides $(\mathrm{p}>0.05)$.

The volumes of components of kidney using the Cavalieri principles are shown in Figure 5. Volumes of the left and right cortex, medulla, and pelvis renalis using the Cavalieri principle were not found to be statistically significant $(\mathrm{p}>0.05)$. However, differences between sexes were found to be statistically significant $(\mathrm{p}<0.05)$.

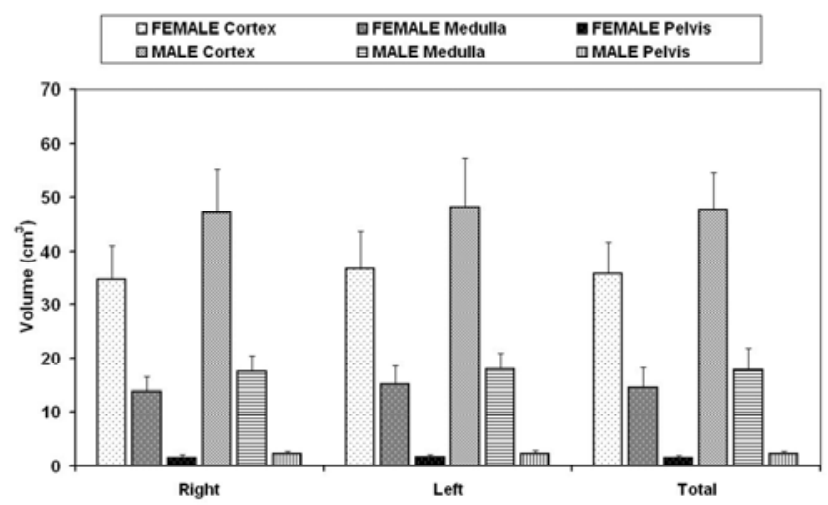

Figure 5. The volume of components of kidney $\left(\mathrm{cm}^{3} \pm \mathrm{SD}\right)$ using the Cavalieri principles.

Şekil 5. Cavalieri prensibine göre böbrek bileşenlerinin hacimleri $\left(\mathrm{cm}^{3} \pm \mathrm{SD}\right)$.

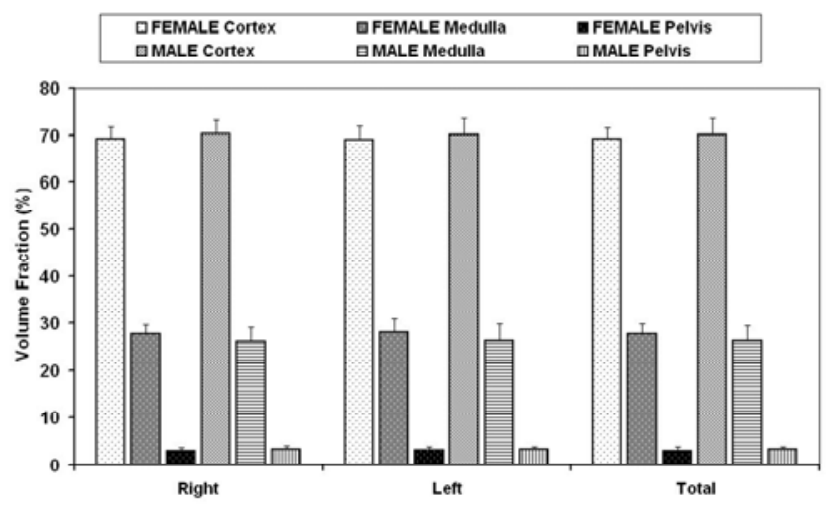

Figure 6. The percentage composition of male and female kidneys $(\% \pm \mathrm{SD})$.

Şekil 6. Erkek ve dişi böbreklerinin bileşenlerinin yüzdesel dağılımı $(\% \pm \mathrm{SD})$.

Volume fraction of kidney components: The volume fractions of the components of kidney were estimated 
stereologically. The mean values for kidney weight and total kidney volume are shown in Figure 6. The mean of volume fraction of cortex, medulla and pelvis in all subjects were $69.7 \%, 27.1 \%$ and $3.2 \%$, respectively. The volume fractions of cortex, medulla and pelvis were $69.2 \%, 27.7 \%$, and $3.1 \%$ for females, respectively, whereas in males, the volume fractions were $70.2 \%$, $26.4 \%$ and $3.4 \%$, respectively. The volume fraction values were not statistically different between the genders $(p>0.05)$. The volume fraction of the cortex, medulla, and pelvis were not found to be statistically significant between the left and right sides ( $\mathrm{p}>0.05$ ).

Coefficients of error of stereological procedure: The coefficient of error in the estimated volumes of total kidney, medulla and pelvis obtained from the $0.65 \mathrm{~cm}$ sections of kidneys of female, calculated using the Cavalieri principle, were $3 \%, 6 \%, 8 \%$, and $17 \%$, respectively. In males, on the other hand, these coefficients were $3 \%, 5 \%, 8 \%$, and $12 \%$, respectively.

\section{Discussion and Conclusion}

Renal volume is clinically important data because renal size gives insight into renal functional reserve (8). The size and pre-transplant glomerular filtration rate of a donated kidney influence post-transplant outcome. Transplantation of larger kidneys confers an outcome advantage and larger kidneys should be preferred when selecting from otherwise similar living donors (26). Kidney volume and the thickness of the total parenchyma or renal cortex have been used to predict overall renal function in normal individual and in those with chronic renal disease (31). Cortical thickness and cortical area have been shown to help predict the presence of unilateral renal artery stenosis with far greater sensitivity and accuracy than renal bipolar length in patients with early atherosclerotic renovascular disease or fibromuscular dysplasia (7, 21, 22). Brenner et al. (5) reported that the reduction in the number of nephrons, i.e. the volume of cortex, might cause high blood pressure and kidney failure (6). However, using only the thickness of cortex or parenchyma of the kidney may provide biased data since the third dimension is omitted.

There is a consensus about kidney size being related to body height, body surface area, and to some extent also to body weight $(15,30)$. However, the highest correlation coefficient was with lean body mass. Hence, for scientific purposes it seems crucial that any evaluation of kidney size should take body composition into consideration (30). In the light of this data, renal volume should be standardized by lean body mass rather than by body surface area and weight, even though this involves a more invasive and cost-intensive procedure.
Otherwise, comparing solely the kidney volumes between two groups (i.e. control and experimental groups) may not provide reliable data.

The volume fraction is a simple and very widely used parameter in biomedical science $(1,14,17,18)$. Thus, it is used to express the proportion of a phase or component within the whole structure. Since the normal or pathological composition of interested organ is evaluated it is not necessary to further standardize the body weight or height of the subjects in the groups. This is very important advantage of the volume fraction approach over volume estimation solely.

According to our findings, the body weight and of course the kidney volume of the males were larger than those of females as expected. However, there was not a statistically difference between the male and female values regarding the volume fraction of the subcomponents of kidney. In the light of this data, we can propose that the composition of the kidney did not show differences between the genders.

It has been observed that studies carried out using stereological methods on organs generally question the reliability of the method. Accordingly, various sections from the same material have been analyzed and compared, and no significant difference has been observed $(2,4,9,27)$.

We also did not observe differences between the estimations of kidney volume using either the Archimedean principle of "liquid dynamics" or the Cavalieri method. The volumes of cortex, medulla, and pelvis could only be measured stereologically using the Cavalieri method. Consequently, the measurement of volume using the Archimedean principle for the purpose of understanding the structures of functional parts of kidneys was found to be inefficient. However, the measurements of Archimedean principle were used as the gold standard for the estimation of Cavalieri principle in this study. The components of kidney could be estimated accurately and efficiently using the Cavalieri principle.

The size of kidneys following preparation for investigation under a microscope might change: a 50\% reduction (shrinkage) in the volume might be observed due to soaking in paraffin $(13,20)$. Furthermore, a volumetric shrinkage of $5 \%$ to $15 \%$ could be seen in kidneys due to the effects of solutions used to fixate tissues $(20,32)$. There also could be changes in the size of kidney tissue (tissue loss) sliced for analysis (4). In the present investigation, kidneys obtained in slaughterhouse were immediately immersed and stored in the fixative solution ( $10 \%$ formalin) for 10 days to preserve their structures. The amount of volumetric shrinkage caused by the formalin solution used in this study could not be determined. 
The estimation of CE in stereological methods is an effective way of determining the adequate section number and sufficient point density in the grids. A CE less than $5 \%$ is an acceptable value for a study $(10,27$, 29). In this investigation, $\mathrm{CE}$ values ranged between $3 \%$ and $17 \%$ for females, and $3 \%$ and $12 \%$ for males. The average $\mathrm{CE}$ of the pelvis renalis region in kidneys were 0.17 in females, and 0.12 in males, which are high values for stereological techniques. Since the number of sections containing the pelvis is inadequate, the $\mathrm{CE}$ becomes higher. If the researcher alters section thickness to obtain at least 6-7 sections containing the pelvis, the CE will decrease dramatically.

Our results show that the volume and volume fraction of the total kidney and its components could be evaluated practically on physical sections using the method proposed in this study. The estimation of the volume and volume fraction using the stereological approach applied in this study provides unbiased data about the volumetric quantities of the kidney. The values obtained in this way are reliable and reproducible. Moreover, the stereological approach could be easily applied without altering routine procedures and the obtained data show little inter-observer variation both at microscopic and macroscopic levels $(24,29)$. Finally, the results of this research will provide an insight for investigation and comparison of hypertrophy, atrophy, and tumor formation in the kidneys.

\section{References}

1. Basoglu A, Buyukkarabacak Y, Sahin B, Kaplan S (2007): Volumetric evaluation of the lung expansion following resection: a stereological study. Eur $\mathrm{J}$ Cardiothorac Surg, 31, 512-517.

2. Beech DJ, Roche ED, Sibbons PD, Rossdale PD, Ousey JC (2000): Stereological estimation of volume-weighted mean glomerular volume from arbitrary sections of the equine kidney. J Anat, 197, 307-311.

3. Bertram JF (1995): Analyzing renal glomeruli with the new stereology. Int Rev Cytol, 161, 111-172.

4. Bertram JF (2001): Counting in the kidney. Kidney Int, 59, 792-796.

5. Brenner BM, Garcia DL, Anderson S (1988): Glomeruli and blood pressure: Less of one, more the other? Am J Hypertens, 1, 335-347.

6. Brenner BM, Chertow GM (1993): Congenital oligonephropathy: An inborn cause of adult hypertension and progressive renal injury? Curr Opin Nephrol Hypertens, 2, 691-695.

7. Cheung CM, Shurrab AE, Buckley DL, Hegarty J, Middleton RJ, Mamtora H, Kalra PA (2006): $M R$ derived renal morphology and renal function in patients with atherosclerotic renovascular disease. Kidney Int, 69 , 715-722.

8. Coulam CH, Bouley DM, Sommer FG (2002): Measurement of renal volumes with contrast-enhanced MRI. J Magn Reson Imaging, 15, 174-179.
9. Glaser JR, Glaser EM (2000): Stereology, morphometry and mapping: the whole is greater than the sum of its parts. J Chem Neuroanat, 20, 115-126.

10. Gundersen HJ, Jensen EB (1987): The efficiency of systematic sampling in stereology and its prediction. $\mathrm{J}$ Microsc, 147, 229-263.

11. Gundersen HJG, Bendtsen TF, Korbo L, Marcussen N, Móller A, Nielsen K, Nyengaard JR, Pakkenberg B, Sórensen FB, Vesterby A, West MJ (1988): Some new, simple and efficient stereological methods and their use in pathological research and diagnosis. APMIS, 96, 379-394.

12. Gundersen HJ, Jensen EB, Kieu K, Nielsen J (1999): The efficiency of systematic sampling in stereologyreconsidered. J Microsc, 193, 199-211.

13. Hanstede JG, Gerrits PO (1983): The effects of embedding in water-soluble plastics on the final dimensions of liver sections. J Microsc, 131, 79-86.

14. Howard CV, Reed MG (1998): Unbiased stereology. Three-dimensional measurement in microscopy. Bios Oxford, 55-68.

15. Kim YS, Moon JI, Kim DK, Kim SI, Park K (2001): Ratio of donor kidney weight to recipient bodyweight as an index of graft function. Lancet, 357, 1180-1181.

16. Lane PH, Belsha CW, Plummer J, Steinhardt GF, Lynch RE, Wood EG (1998): Relationship of renal size, body size, and blood pressure in children. Pediatr Nephrol, 12, 35-39.

17. Mattfeldt T, Gottfried HW, Wolter H, Schmidt V, Kestler HA, Mayer J (2003): Classification of prostatic carcinoma with artificial neural networks using comparative genomic hybridization and quantitative stereological data. Pathol Res Pract, 199, 773-784.

18. Mattfeldt T, Trijic D, Gotffried HW, Kestler HA (2004): Incidental carcinoma of the prostate: clinicopathological, stereological and immunohistochemical findings studied with logistic regression and self-organizing feature maps. BJU Int, 93, 284-290.

19. Mazonakis M, Karampekios S, Damilakis J, Voloudaki A, Gourtsoyiannis N (2004): Stereological estimation of total intracranial volume on CT images. Eur Radiol, 14, 1285-1290.

20. Miller PL, Meyer TW (1990): Effects of tissue preparation on glomerular volume and capillary structure in the rat. Lab Invest, 63, 862-866.

21. Mounier-Vehier C, Lions C, Devos P, Jaboureck O, Willoteaux S, Carre A, Beregi JP (2002): Cortical thickness: an early morphological marker of atherosclerotic renal disease. Kidney Int, 61, 591-598.

22. Mounier-Vehier C, Lions C, Jaboureck O, Devos P, Haulon S, Wibaux M, Carre A, Beregi JP (2002): Parenchymal consequences of fibromuscular dysplasia renal artery stenosis. Am J Kidney Dis, 40, 1138-1145.

23. Nawaratne S, Brien JE, Seeman E, Fabiny R, Zalcberg J, Cosolo W, Angus P, Morgan DJ (1998): Relationships among liver and kidney volumes, lean body mass and drug clearance. J Clin Pharmacol, 46, 447-452.

24. Odaci E, Sahin B, Sonmez OF, Kaplan S, Bas O, Bilgic S, Bek Y, Ergür H (2003): Rapid estimation of the vertebral body volume: a combination of the Cavalieri principle and computed tomography images. Eur J Radiol, 48, 316-326. 
25. Odaci E, Kaplan S, Sahin B, Bas O, Gevrek F, Aygün D, Ünal B, Sönmez OF, Colakoglu S, Bilgic S (2004): Effects of low-dose oxcarbazepine administration on developing cerebellum in newborn rat: A stereological study. Neurosci Res Commun, 31, 28-36.

26. Poggio ED, Hila S, Stephany B, Fatica R, Krishnamurthi V, del Bosque C, Goldfarb D, Herts B, Dennis VW, Heeger PS, Braun W (2006): Donor kidney volume and outcomes following live donor kidney transplantation. Am J Transplant, 6, 616-624.

27. Sahin B, Aslan H, Unal B, Canan S, Bilgic S, Kaplan S, Tumkaya L (2001): Brain volume of the lamb, rat and bird do not show hemispheric asymmetry: A stereological study. Image Anal Stereol, 20, 9-13.

28. Sahin B, Alper T, Kökcü A, Malatyalioglu E, Kosif R (2003a): Estimation of the amniotic fluid volume using the Cavalieri method on ultrasound images. Int J Gynecol Obstet, 82, 25-30.

29. Sahin B, Emirzeoglu M, Uzun A, Incesu L, Bek Y, Bilgic S, Kaplan S (2003b): Unbiased estimation of the liver volume by the Cavalieri principle using magnetic resonance images. Eur J Radiol, 47, 164-167.
30. Schmidt IM, Molgaard C, Main KM, Michaelsen KF (2001): Effect of gender and lean body mass on kidney size in healthy 10-year-old children. Pediatr Nephrol, 16, 366370.

31. Troell S, Berg U, Johansson B, Wikstad I (1988): Comparison between renal parenchymal sonographic volume, renal parenchymal urographic area, glomerular filtration rate and renal plasma flow in children. Scand $\mathrm{J}$ Urol Nephrol, 22, 207-214.

32. Weibel ER, Knight BW (1964): A morphometric study on the thickness of the pulmonary air-blood barrier. J Cell Biol, 21, 367-384.

Geliş tarihi: 23.05.2008 / Kabul tarihi: 15.12.2008

\section{Address for correspondence}

Dr. Gulsun Pazvant

Department of Anatomy,

Faculty of Veterinary Medicine, Istanbul University

33840, Avcllar, Istanbul, Turkey

e-mail:gulsun@istanbul.edu.tr 